\title{
IMPLEMENTATION OF TBC MANAGEMENT PROGRAMS AT RAWA BUNTU PUBLIC HEALTH CENTER CITY OF TANGERANG SELATAN DURING THE COVID-19 PANDEMIC IN 2021
}

\author{
${ }^{1}$ Zulva Nur Rizqy Amalia, ${ }^{2}$ Amira Mhuthia Adila, ${ }^{3}$ Zahro Mufida \\ Faculty of Public Health, Muhammadiyah University of Jakarta \\ Jl. K.H. Ahmad Dahlan, Cireundeu, Ciputat, Jakarta Selatan 15419 \\ E-mail: zulvaamalia06@gmail.com
}

\begin{abstract}
Indonesia is included in 8 countries that account for $2 / 3$ of TB cases worldwide. Of these cases, only $67 \%$ were found and treated, so there were 283,000 patients. The COVID-19 pandemic has also exacerbated 2 determinants of TB incidence, namely decreased income and malnutrition. This research is qualitative research with the descriptive method by conducting interviews with 5 informants. The COVID-19 pandemic has brought changes to the implementation of the TB program at the Public Health Center, especially in the aspects of health promotion, surveillance, risk factor control, and case management. Health promotion is carried out online, surveillance is hampered so that it is not optimal, risk factor control is still running and case handling still requires the role of cadres.
\end{abstract}

Keywords: TB program, covid-19 pandemic, public health center 


\section{INTRODUCTION}

The COVID-19 pandemic poses a challenge to health systems around the world. When the health system is preoccupied with the pressing need for care for people with COVID-19, direct and indirect deaths from diseases that can be repaired and treated, do not exacerbate Tuberculosis (TB) disease (WHO, 2020b). The World Health Organization (2020a) said that this pandemic poses a threat that could hinder efforts to tackle the global burden of TB disease. It is estimated that the number of deaths from TB globally could increase by around $0.2-0.4$ million in 2020 alone if health services are pandemic.

Geographically, the majority of TB sufferers are in the Southeast Asian region as much as $44 \%$ of the global total (WHO, 2020a). Indonesia is included in 8 countries that account for $2 / 3$ of TB cases worldwide. The country with the first most TB cases in the world is occupied by India, followed by Indonesia in the second position with 845,000 cases. Of these cases, only $67 \%$ were found and treated, so $283,000 \mathrm{~TB}$ patients have not been treated and are at risk of becoming a source of transmission for people around them (PPNI DPP, 2021). TB cases in Indonesia caused 98,000 deaths or the equivalent of 11 deaths/hour (Kemenkes RI, 2020a). In addition, Indonesia and 13 other countries are included in the list of high burden countries (HBC) for the three TB indicators, namely TB, TB/HIV, and MDR (Multidrug-resistant)-TB. This shows that Indonesia has big problems in dealing with TB disease (Ministry of Health, 2018). TB cases by province indicate that Banten has not yet reached the CDR (Case Detection Rate) recommended by WHO, which is $90 \%$. The proportion of TB cases in children < 15 years in Banten also increased, namely 1,773 from 18,181 cases in 2018 and 2,283 out of 21,994 cases in 2019 (Kemenkes RI, 2020b).

TB control efforts in Indonesia are currently affected by the COVID-19 pandemic. This is because almost all resources, both in the health sector and other sectors, are optimized to handle COVID-19 (Ika, 2021). Of the 845 thousand TB cases that should have been found in 2020, only 350 thousand or 349 thousand cases were found. The estimated percentage of TB cases found has also decreased, which is only 30\% in 2020 from 60\% of cases in 2018 and 2019 (Ministry of Health of the Republic of Indonesia, 2021). Before the COVID-19 pandemic alone, there were still things that needed to be improved in TB control in Indonesia. In 2019, Indonesia became the third country out of five countries that accounted for more than half of the global gap (10\%) in TB case reports in addition to being the largest contributor in TB case reporting (331,703 cases in 2015 to 562,049 in 2019 (WHO, 2020).

Based on research conducted by Zarwita, Rasyid, and Abdiana, (2019), it was found that the implementation of the discovery of pulmonary TB patients in the pulmonary TB control 
program at the Balai Selasa Health Center was still not optimal and the coverage of patient discovery was still low. The results of the research conducted by Sofiyatun (2019) also stated that there was a shortage of staff and facilities, lack of consistency in communication and commitment of program implementers to patients, case finding was still not actively carried out, information provision was only carried out between individuals so that the level of public knowledge was low. , and to lose commitment to pulmonary TB patients at the Tlogosari Kulon Health Center. Meanwhile, a similar study conducted by Marahmah and Hasibuan (2021) stated that the implementation of the pulmonary TB control program with the DOTS strategy at the Panyabungan Jae Health Center, Mandailing Nata Regency was running optimally although there were still obstacles, such as community knowledge about TB was still low, the majority of the community's economy was middle class. down, and people are still shy in doing the treatment.

Apart from the high magnitude of the problem of pulmonary TB and the prevention efforts that have not been optimal in some places, tuberculosis itself needs to be watched out for. This is because tuberculosis is an infectious disease that can attack anyone, especially those of productive age/still actively working (15-50 years) and children ( $<15$ years). The source of TB transmission is TB patients with TB germs in their sputum. This disease is transmitted through droplets of patients who do not apply etiquette when coughing or sneezing. One cough can produce about 3000 sputum sprinkling containing 0-3500 M. tuberculosis germs. Meanwhile, when a sneeze can produce a splash containing as many as 4500-1,000,000 M. tuberculosis germs. The infection will occur when a susceptible person (low immunity) breathes air containing the sputum (Ministry of Health, 2020).

In addition, the COVID-19 pandemic has also exacerbated 2 determinants of TB incidence, namely decreased income and malnutrition. Decreased income due to loss of income or unemployment can increase the percentage of TB sufferers and create a burden in financing TB treatment (WHO, 2020a). Meanwhile, someone with a Body Mass Index (BMI) of less than $18.5 \mathrm{~kg} / \mathrm{m} 2$ has a 4 times greater risk of contracting TB (Purwaningsih, 2019).

The results of an initial study of data from the South Tangerang City Health Office showed that there were 111 cases of tuberculosis at the Rawa Buntu Health Center in 2020. The number of TB cases in children aged 0-14 years was 15 cases and the CNR (Case Notification Rate) was 45 cases per 100,000 population.

Based on this description, it is deemed necessary to research the Public Health Center located in South Tangerang City, namely the Rawa Buntu Health Center to know the implementation of the TB control program during the COVID-19 pandemic. 


\section{METHODS}

This type of research is descriptive with a qualitative approach. This research was conducted in April - June 2021 at the Rawa Buntu Health Center. The data of this study were obtained from in-depth interviews. The informants in this study, namely the TB program holders of the South Tangerang City Health Office and the Rawa Buntu Health Center, and the Drug Drinking Supervisor at the Rawa Buntu Health Center. The informant determination technique used is the purposive sampling technique. Validation of this research data using source triangulation. Data analysis in this study includes data reduction, data presentation, and concluding/verification.

\section{RESULTS AND DISCUSSIONS}

Based on the results of interviews conducted with informants, information was obtained that health promotion about pulmonary TB during the COVID-19 pandemic to the general public, cadres, and patients was carried out online through the WhatsApp application. Before the COVID-19 pandemic, health promotion about pulmonary TB was carried out directly by the holders of the pulmonary TB program and health promotion personnel. Usually held every 2-3 months. Meanwhile, the promotion of pulmonary TB health during the COVID-19 pandemic carried out by the local health office with pulmonary TB program holders at their regional health centers was carried out by using Personal Protective Equipment (PPE) which was stricter than before, which only used masks.

According to PMK No. 67 of 2016 article 7, it is stated that the purpose of health promotion in TB control aims to:

a) increase the commitment of policymakers;

b) improve the integration of program implementation; and

c) empowering the community

The Rawabuntu Public Health Center carries out a comprehensive health promotion. Education related to TB is still carried out in conjunction with other health education, so it is less focused on promotions related to TB. According to research conducted by Ratu and Wilis in 2021, health promotion should be carried out by focusing more on tuberculosis problems such as preventing the transmission of pulmonary $\mathrm{TB}$, treatment for pulmonary $\mathrm{TB}$, and a clean and healthy lifestyle, so that it can change people's attitudes and behavior and eliminate stigma and discrimination of the public and health workers against pulmonary TB (Ratu \& Wilis, 2021).

Based on research conducted by Sukmawati in 2017 on the effectiveness of TB counseling, it was found that booklet media is effective as a means of information to increase knowledge about TB in patients and families, especially during this pandemic people rarely come to health 
care facilities. Another study in Baubau in 2020 on health promotion media found that online education using video media as well as leaflets proved to be effective in educating the public (Sabarudin et al., 2020).

According to the results of interviews with informants, it is known that the implementation of pulmonary TB surveillance during the COVID-19 pandemic did not run optimally. This is because health workers feel confused due to being surprised by the COVID19 pandemic and people are afraid to come to the Public Health Center and are afraid to be visited by Public Health Center officers because they are wearing Personal Protective Equipment (PPE) so that it affects the achievement of TB case finding, which is less than estimated. The implementation of surveillance is assisted by cadres in the local Public Health Center area in terms of reporting residents suspected of having pulmonary TB.

Nevertheless, TB surveillance must still be carried out so that early TB detection can be known and there is no spike in TB cases after the pandemic. This is supported by the Provincial Health Office and the Ministry of Health with the issuance of technical guidelines for TB surveillance which can later be directly forwarded to program holders in each Puskesmas. The Ministry of Health through the Directorate General of Disease Prevention and Control also stated that TB services should not be stopped, including if TB service facilities (especially TBOR referral services) are also places for COVID-19 referral services. Health workers involved in TB control programs should also have experience and capacity in active case finding and contact tracing. Based on the regulation of the Minister of Health of the Republic of Indonesia No. 67 of 2016 concerning tuberculosis control, TB case findings can be carried out actively and passively. Either through investigation, screening, or direct patient examination. Screening under special conditions can also be done as well as during the current pandemic. However, TB surveillance must also meet the attributes of a TB surveillance system such as flexibility, high data quality, acceptability, timeliness, representativeness, high stability, and simplicity (Uddin, Wahyuni, and Setiawan, 2021).

Based on the results of interviews with informants, information was obtained that the control of pulmonary TB risk factors during the COVID-19 pandemic was still being carried out, both within the Public Health Center and in the community. Socialization regarding PHBS and Germas in the community is still being carried out, although online.

This is in line with the recommendation of the Minister of Health through PERMENKES RI number 67 of 2016 concerning Tuberculosis Control where TB risk factor control can be carried out through cultivating clean and healthy living behaviors, coughing ethical behavior, increasing body resistance, and so on (Ministry of Health, 2016). . Another 
study conducted by Adrian et al also stated that controlling TB risk factors can be realized through household activities with clean and healthy living behavior (PHBS) (Adrian, Purnomo and Agustiyara, 2020).

According to information provided by informants, it is known that finding cases of pulmonary TB during the COVID-19 pandemic is more difficult. This is because there are restrictions on the number of people who come to the Public Health Center and people no longer come to the Public Health Center for fear of contracting COVID-19. In addition, the community also feels afraid when visited by Public Health Center officers wearing Personal Protective Equipment (PPE). The discovery of pulmonary TB cases during the COVID-19 pandemic at the local health center was assisted by local pulmonary TB cadres by suggesting \& reporting residents suspected of having pulmonary TB to the Public Health Center after the residents took several treatments but their condition did not improve.

In addition to case findings, information was also obtained regarding the handling of pulmonary TB cases during the COVID-19 pandemic. The informants stated that to maintain the consistency of TB patients in taking Anti Tuberculosis Drugs (OAT) is to give them enthusiasm, understanding, and education. Cooperation and coordination in the handling of pulmonary TB cases between the holders of the pulmonary TB program and their drug-taking supervisors (PMOs) went well.

According to PMK No. 67 of 2016 article 11, generally case finding is carried out actively and passively. Active case finding is carried out as follows:

a) Investigation and Examination of Contact Cases

b) mass screening, especially in vulnerable groups and at-risk groups

c) screening under special circumstances

While passively case finding is done through examination of patients who come to health care facilities.

Handling positive TB cases before and after the pandemic still requires the role of a PMO (Drug Drinking Supervisor). Drug-taking supervisors greatly affect the success rate of recovery in patients suffering from TB by directly monitoring patients on their regularity in taking drugs and checking sputum regularly until they are declared cured (Taswin, Izan, Wahyudin, \& Damar, 2021).

According to a study conducted by Mujamil, et al in 2021 at a health center in the Kendari area, it was found that patient knowledge and the role of health workers affected adherence to taking medication during the COVID-19 pandemic (Ode, Sety, Zainuddin, \& Kusnan, 2021). 
TB program managers at the District/City Health Offices must proactively monitor the implementation of treatment at Public Health Center and hospitals using all possible communication modalities, including anticipating the imposition of conditions for restricting individual movement or "lockdown" in an area (P2PML Ministry of Health RI, 2020). Therefore, TB program managers are expected to make a contingency plan for TB treatment by making:

a) Planned needs for $\mathrm{TB}$ drugs and other logistics including masks with various considerations of the conditions that occur.

b) Mapping and appointment of temporary TB RO referral health facilities (separate from COVID-19 health facilities) signed by the Head of the Local Health Office.

c) Mapping and appointment of other health facilities for laboratory services in the context of TB diagnosis signed by the Head of the Local Health Office, if the old network needs to be adjusted due to the handling of COVID-19 in the area.

d) Plans to monitor the supervision of TB patients taking medication using digital technology or WA numbers, hotlines according to local capabilities.

e) Mapping in local community involvement for patient assistance.

\section{CONCLUSION AND SUGGESTIONS}

The implementation of the TB control program at the Rawa Buntu Health Center during the COVID-19 pandemic based on health promotion, TB surveillance, TB risk factor control, as well as finding and handling TB cases experienced various obstacles and was not running optimally. Regulations and policies to prevent and control COVID-19 cases reduce the performance of TB control activities. Health promotion is carried out online, surveillance is hampered so that it is not optimal, risk factor control is still running and case handling still requires the role of cadres.

It is hoped that all competent authorities will be more massive and responsive to the impacts arising from the COVID-19 pandemic, establish cross-sectoral collaboration, increase the quantity and quality of health workers in the TB health facilities, innovate in health promotion, create a TB service hotline in the TB department. each region, as well as being proactive in monitoring and evaluating the implementation of TB control programs in all health care facilities.

The limitation of this study is that data validation only uses source triangulation so that there is still the possibility of bias between the statements of the informants and the actual data and the researchers are still not experienced in researching so that the process is still not optimal. 


\section{REFERENCES}

Adrian, M. M., Purnomo, E. P. and Agustiyara, A. W. (2020) 'Implementasi Kebijakan Pemerintah PERMENKES NO 67 Tahun 2016 Dalam Penanggulangan Tuberkulosis di Kota Yogyakarta', Jurnal Kebijakan Kesehatan Indonesia: JKKI, 9(2), pp. 83-88. Available at: https://jurnal.ugm.ac.id/jkki/article/view/55965.

DPP PPNI (2021) Hari TBC Sedunia 2021: Harus Melakukan Tindakan Promotif Preventif, Persatuan Perawat Nasional Indonesia.

Ika (2021) Terganggu Pandemi COVID-19, Penemuan Kasus Tuberkulosis di Indonesia Menurun, Universitas Gadjah Mada.

Kemenkes RI (2020a) 'Panduan Peringatan Hari Tuberkulosis Sedunia Tahun 2020', in, pp. 130. Available at: https://promkes.kemkes.go.id/peringatan-hari-tuberkulosis-sedunia-htbstahun-2021 (Accessed: 27 March 2021).

Kemenkes RI (2020b) Profil Kesehatan Indonesia Tahun 2019, Kementrian Kesehatan Republik Indonesia. Jakarta: Kementerian Kesehatan Republik Indonesia.

Kementerian Kesehatan RI (2016) 'PERATURAN MENTERI KESEHATAN REPUBLIK INDONESIA NOMOR 67 TAHUN 2016', Dinas Kesehatan, p. 163.

Kementerian Kesehatan RI (2018) Info Data dan Informasi Tuberkulosis Tahun 2018, Kementerian Kesehatan RI. Available at: https://pusdatin.kemkes.go.id/resources/download/pusdatin/infodatin/infodatintuberkulosis-2018.pdf.

Kementerian Kesehatan RI (2021) Cara Sama Tanggulangi TBC dan COVID-19. Available at: https://www.kemkes.go.id/article/view/21032400001/cara-sama-tanggulangi-tbc-dancovid-19.html (Accessed: 27 March 2021).

Kementrian Kesehatan RI (2020) Apa itu TBC. Available at: https://tbindonesia.or.id/informasi/tentang-tbc/apa-itu-tbc/ (Accessed: 27 March 2021).

Marahmah, M. and Hasibuan, R. (2021) 'Implementasi Program Penanggulangan TB Paru dengan Strategi Directly Observed Treatment Shortcourse di Puskesmas Panyabungan Jae Kabupaten Mandailing Natal', Jurnal Akademika Baiturrahim Jambi, 10(1), p. 83. doi: 10.36565/jab.v10i1.284.

Ode, L. et al. (2021) 'Analisis Faktor Yang Berhubungan Terkait Kepatuhan Minum Obat Pasien Tuberkulosis Paru BTA+ di Masa Pandemi Covid 19 di Puskesmas Wilayah Kota Kendari', Jurnal Ilmiah Ilmu Keperawatan, 12.

P2PML Kemenkes RI (2020) 'PROTOKOL TATA LAKSANA PASIEN TB DALAM MASA PANDEMI COVID 19', p. شماره 89-117. 
Purwaningsih, F. (2019) Mengapa Tubuh Penderita TBC Cenderung Kurus?, Rumah Sakit Paru

Respira. Available at: http://rsprespira.jogjaprov.go.id/mengapa-tubuh-penderita-tbccenderung-kurus/ (Accessed: 27 March 2021).

Ratu, N. and Wilis, C. (2021) 'Analisis Pelaksanaan Program Penanggulangan Tuberkulosis Paru Di Puskesmas Purwoyoso Kota Semarang', 20(1).

Sabarudin et al. (2020) 'Efektivitas Pemberian Edukasi secara Online melalui Media Video dan Leaflet terhadap Tingkat Pengetahuan Pencegahan Covid-19 di Kota Baubau', Jurnal Farmasi Galenika (Galenika Journal of Pharmacy) (e-Journal), 6(2), pp. 309-318. doi: 10.22487/j24428744.2020.v6.i2.15253.

Sofiyatun, V. (2019) 'Implementasi Program penanggulangan Tuberkulosis Paru', Higeia Journal of Public Health, 3(1), pp. 74-86.

Sukmawati, E. (2017) 'Efektifitas Penyuluhan Kesehatan Terhadap Pengetahuan Perawatan Pasien Tuberkulosis (TB)', Jurnal Ners Lentera, 5(1), pp. 9-20.

Taswin et al. (2021) 'Peran Pengawas Minum Obat Dan Pendampingan Berobat Ulang Dengan Keberhasilan Pengobatan Tb Paru', 20(1).

Uddin, L., Wahyuni, C. U. and Setiawan, A. Y. (2021) 'Evaluasi Sistem Surveillans TB di Dinas Kesehatan Kabupaten Jember', 4(1), pp. 41-53.

WHO (2020a) Global Tuberculosis Report.

WHO (2020b) Pelayanan kesehatan berbasis komunitas, termasuk penjangkauan dan kampanye, dalam konteks pandemi COVID-19.

Zarwita, D., Rasyid, R. and Abdiana, A. (2019) 'Analisis Implementasi Penemuan Pasien TB Paru dalam Program Penanggulangan TB Paru di Puskesmas Balai Selasa', Jurnal Kesehatan Andalas, 8(3), p. 689. doi: 10.25077/jka.v8i3.1058. 
